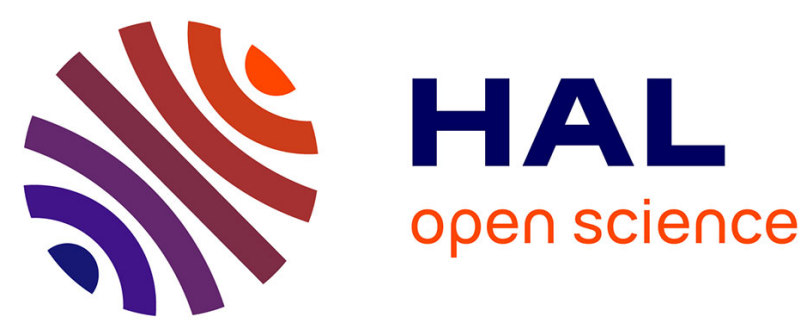

\title{
Harmonisation of phenology stages and selected cherry cultivars as bioindicators for climate change
}

\author{
Bénédicte Wenden, Teresa Barreneche, M. Meland, M.M. Blanke
}

\section{To cite this version:}

Bénédicte Wenden, Teresa Barreneche, M. Meland, M.M. Blanke. Harmonisation of phenology stages and selected cherry cultivars as bioindicators for climate change. COST Cherry FA1104 Working Group 2 Cherry Phenology, Modelling and Climate Change, International Society for Horticultural Science (ISHS). INT., Apr 2014, Ullensvang, Norway. 10.17660/ActaHortic.2017.1162.2 hal-02737756

\section{HAL Id: hal-02737756 \\ https://hal.inrae.fr/hal-02737756}

Submitted on 2 Jun 2020

HAL is a multi-disciplinary open access archive for the deposit and dissemination of scientific research documents, whether they are published or not. The documents may come from teaching and research institutions in France or abroad, or from public or private research centers.
L'archive ouverte pluridisciplinaire HAL, est destinée au dépôt et à la diffusion de documents scientifiques de niveau recherche, publiés ou non, émanant des établissements d'enseignement et de recherche français ou étrangers, des laboratoires publics ou privés. 


\title{
Harmonisation of phenology stages and selected cherry cultivars as bioindicators for climate change
}

\author{
B. Wenden ${ }^{1}$, T. Barreneche ${ }^{1}$, M. Meland ${ }^{2}$ and M. M. Blanke ${ }^{3}$
}

${ }^{1}$ INRA Bordeaux, France; ${ }^{2}$ Norwegian Institute of Bioeconomy Research - NIBIO, Ullensvang, Norway: ${ }^{3}$ INRESHorticultural Science, University of Bonn, Auf dem Hüegel 6, D-53121 Bonn, Germany.

\begin{abstract}
Perennial fruit crops phenology such as cherry is an ideal bio-indicator of climate change due to their long-lasting features, in particular, dates of flower opening and full bloom. This implies i) the use of several generations of cherry trees/orchards and ii) the use of the same original cherry cultivars, which existed as bearing trees and were replanted after the orchard had been grubbed. A comparison of available definitions of phenological stages in cherry previously used independently throughout Europe showed overlaps and shortcomings; hence, harmonisation was reached in this respect in the COST Cherry FA 1104 working group 2 (cherry phenology and climate change) based largely on the acceptance of the BBCH scale. This contribution presents the agreed phenology stages in both visual and wording evidence. Similarly, this contribution presents the agreed cultivars to be monitored in future for phenology and climate change effects for harmonisation. For sweet cherry, this EU-wide harmonisation includes 'Burlat', 'Cristobalina' and 'Rita' as early, 'Stella' and 'Van' as medium flowering and 'Sweetheart', 'Regina' and 'Bigarreau Noire de Meched/Germersdorfer' for late flowering cultivars for climate change effects. For sour cherry, this harmonisation resulted in 'Meteor korai' and 'Anglaise Hative' for early flowering, 'Chrisana Pandy' and 'Erdibotermo' for medium flowering and 'Schattemorelle', 'Iiva, Ujfehrtoifurtos (Balaton)' for late flowering.
\end{abstract}

Keywords: cherry (Prunus avium L., Prunus cerasus), climate change, flowering, global warming, low chill, phenology, sustainable horticulture

\section{INTRODUCTION}

Cherry is an ideal candidate for climate change studies (Luedeling et al., 2013a,b), since distinct phenological stages were defined decades ago (Baggiolini, 1952; Lichou, 1990; Meier et al., 1994) and have been recorded by simple means like filing cards for a long time as part of phenology research in the 1970s before computers and climate change emerged. In the 1990 s, these records were often classified as old-fashioned research and no longer continued or research sites closed down or re-located. At the few locations where the records were maintained, it was important that the records continued on the same original cherry cultivars to show any long-term changes in both climate and phenology. In addition, these cultivars are often used as reference in breeding and evaluation programs, thus maintaining observation campaigns. Four phenological definitions or scales have been used to assess cherry flowering in Europe since the 1970s (Fleckinger, Baggiolini, 1952; Lichou, 1990; Meier et al., 1994). The combination of such historic meteorological and phenological data from the same site are now considered a valuable tool and treasure in assessing the impacts of climate change on a local scale.

The objective of this work was to harmonise terminology for phenological stages and provide a guideline for future European phenology records in cherry and beyond.

\section{MATERIAL AND METHODS}

Phenological data on filing cards included calendar dates of first flower opening (BBCH 
61), full bloom (BBCH 65 or F1040 DD), harvest (BBCH 81) and leaf drop (BBCH 95) as well as late frost and consequent yield loss for a range of cherry cultivars, using only fruit bearing trees at the time. BBCH stages harmonisation for observation, together with reference cultivars for sweet and sour cherries were agreed within the meeting held by the COST Cherry FA 1104 working group 2 (cherry phenology and climate change) in Ullensvang (April 2014).

\section{RESULTS AND DISCUSSION}

\section{Harmonisation of phenology stages in cherry}

Figure 1a-f shows the descriptions for the agreed phenology stages for cherry, largely based on the BBCH scale (Meier et al., 1994).

\begin{tabular}{|c|c|c|c|c|c|}
\hline \multicolumn{3}{|c|}{ ВBCH } & \multicolumn{2}{|c|}{ Description } & \multirow[b]{2}{*}{$\begin{array}{c}\text { Blühbe-ginn; } \\
10 \% \text { der } \\
\text { Blüten offen }\end{array}$} \\
\hline 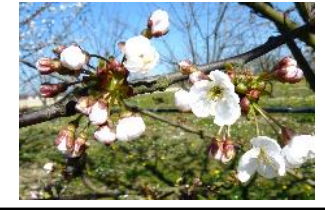 & 61 & $\begin{array}{l}\text { Beginning of } \\
\text { flowering: } \\
\text { about } 10 \% \text { of } \\
\text { flowers open }\end{array}$ & $\begin{array}{l}\text { Début de la } \\
\text { floraison: } \\
\text { environ } 10 \% \\
\text { des fleurs sont } \\
\text { ouvertes }\end{array}$ & $\begin{array}{l}\text { Comienzo de la } \\
\text { floración: } \\
\text { aproximadamente } \\
\text { el } 10 \% \text { de las } \\
\text { flores están } \\
\text { abiertas }\end{array}$ & \\
\hline & 65 & $\begin{array}{l}\text { Full flowering: } \\
\text { at least } 50 \% \text { of } \\
\text { flowers open, } \\
\text { first petals } \\
\text { falling }\end{array}$ & $\begin{array}{l}\text { Pleine floraison: } \\
\text { au minimum } \\
50 \% \text { des fleurs } \\
\text { épanouies, les } \\
\text { premiers } \\
\text { pétales tombent }\end{array}$ & $\begin{array}{l}\text { Plena floración: } \\
\text { por lo menos } 50 \% \\
\text { de las flores están } \\
\text { abiertas, los } \\
\text { primeros pétalos } \\
\text { caen }\end{array}$ & $\begin{array}{l}\text { Vollblüte; } \\
\text { 50\% der } \\
\text { Blüten offen }\end{array}$ \\
\hline & 67 & $\begin{array}{c}\text { Flowers } \\
\text { fading: } \\
\text { majority of } \\
\text { petals fallen }\end{array}$ & $\begin{array}{l}\text { La floraison } \\
\text { s'achève, la } \\
\text { plupart des } \\
\text { pétales sont } \\
\text { tombés }\end{array}$ & $\begin{array}{l}\text { Se termina la } \\
\text { floración, la } \\
\text { mayoría de los } \\
\text { pétalos han caído }\end{array}$ & $\begin{array}{l}\text { Abgehende } \\
\text { Blüte, mei- } \\
\text { sten Blü- } \\
\text { tenblätter } \\
\text { abgefallen }\end{array}$ \\
\hline & 69 & $\begin{array}{c}\text { End of } \\
\text { flowering: all } \\
\text { petals fallen }\end{array}$ & $\begin{array}{c}\text { Fin de floraison: } \\
\text { tous les pétales } \\
\text { sont tombés }\end{array}$ & $\begin{array}{l}\text { Final de floración: } \\
\text { todos los pétalos } \\
\text { se han caído }\end{array}$ & $\begin{array}{l}\text { Blühende, } \\
\text { alle Blü- } \\
\text { tenblätter } \\
\text { abgefallen }\end{array}$ \\
\hline & 72 & $\begin{array}{l}\text { Green ovary } \\
\text { surrounded by } \\
\text { dying sepal } \\
\text { crown, sepals } \\
\text { beginning to } \\
\text { fall }\end{array}$ & $\begin{array}{l}\text { Ovaire vert } \\
\text { entouré de } \\
\text { sépales fanés, } \\
\text { les premiers } \\
\text { sépales tombent }\end{array}$ & $\begin{array}{l}\text { Ovario verde } \\
\text { rodeado de una } \\
\text { corona de sépalos } \\
\text { marchitos, los } \\
\text { primeros sépalos } \\
\text { caen }\end{array}$ & $\begin{array}{l}\text { Grüner Fru- } \\
\text { chtknoten } \\
\text { von abster- } \\
\text { benden Kel- } \\
\text { chblattkranz } \\
\text { umgeben }\end{array}$ \\
\hline & 85 & $\begin{array}{l}\text { Maturity base } \\
\text { on colouring }\end{array}$ & $\begin{array}{c}\text { Maturité } \\
\text { évaluée par la } \\
\text { couleur }\end{array}$ & $\begin{array}{c}\text { Maduración } \\
\text { basada en el color } \\
\text { del fruto }\end{array}$ & $\begin{array}{c}\text { Fortgeschritt } \\
\text { ene Frucht- } \\
\text { ausfärbung }\end{array}$ \\
\hline$\because-240$ ising & 92 & $\begin{array}{l}\text { Senescence: } \\
\text { Leaves begin } \\
\text { to discolour, at } \\
\text { least } 10 \% \text { of } \\
\text { yellow leaves }\end{array}$ & $\begin{array}{c}\text { Sénescence : } \\
\text { début de } \\
\text { décoloration des } \\
\text { feuilles, au } \\
\text { moins } 10 \% \text { de } \\
\text { feuilles jaunes }\end{array}$ & $\begin{array}{l}\text { Senescencia: } \\
\text { Inicio de la } \\
\text { decoloración de } \\
\text { las hojas, por lo } \\
\text { menos } 10 \% \text { de } \\
\text { hojas amarillas }\end{array}$ & $\begin{array}{l}\text { Beginn der } \\
\text { Laubblatt- } \\
\text { verfärbung }\end{array}$ \\
\hline
\end{tabular}

Figure 1. Developmental stages for cherry ( ${ }^{\odot}$ Hélène Christmann, INRA). 
Table 1. Phenology harmonisation for future flowering records of sweet/sour cherry (Meier et al., 1994).

\begin{tabular}{lccc}
\hline Category & Meier scale & Definition & Criterion \\
\hline BBCH 61 & Blühbeginn & Beginning of flowering & $10 \%$ of flowers open \\
BBCH 65 & Vollblüte & Full bloom & $50 \%$ flowers open \\
BBCH 67 & Blühende & End of flowering & $90 \%$ flowers open \\
BBCH 72 & Steinhärtung & & Pit hardening \\
BBCH 85 & Fruchtreife & Fruit maturity & \\
BBCH 92 & Blattfall & Senescence & $10 \%$ of leaves yellow \\
\hline
\end{tabular}

Harmonisation of cherry cultivars to be monitored in the EU for climate change effects A major result and outcome of the EU COST Cherry FA 1104 WG 2 (Cherry phenology and climate change) meeting was the acceptance of one universal scale for all European countries (Table 1) and agreed standard cultivars (Table 2) for phenology monitoring. Cultivars were selected on the basis of early, medium and late flowering and most widely grown throughout Europe.

Table 2. Phenology harmonisation for future flowering records of sweet and sour cherry.

\begin{tabular}{lcc}
\hline Category & Sweet cherry flowering & Sour cherry flowering \\
\hline Early flowering & Burlat, Christobalina, Rita & Meteor korai, Anglaise Hative \\
$\begin{array}{l}\text { Medium } \\
\text { flowering }\end{array}$ & Stella, Van & Chrisana Pandy, Erdibotermo \\
Late flowering & Sweetheart, Regina, & Schattenmorelle, liva, Ujfehrtoifurtos \\
& Noire de & (Balaton) \\
& Meched/Germersdorfer & \\
\hline
\end{tabular}

The BBCH-scale is a scale used to identify the phenological development stages of a plant. A series of BBCH-scales have been developed for a range of crop species. Phenological development stages of plants are used in a number of scientific disciplines (crop physiology, phytopathology, entomology and plant breeding) and in the agriculture industry (timing of pesticide application, fertilisation, agricultural insurance). The BBCH-scale uses a decimal code system, which is divided into principal and secondary growth stages, and is based on the cereal code system (Zadoks scale) . BBCH officially stands for "Biologische Bundesanstalt, Bundessortenamt und CHemische industrie.

\section{CONCLUSIONS}

The experts of the EU COST Cherry agreed to use the detailed and more precise German $\mathrm{BBCH}$ throughout Europe in the future for cherry flower monitoring and provide detailed descriptions in all European languages plus pictorial digital evidence in this chapter of this Acta Horticulturae. Continued data acquisition throughout Europe will support the development of predictive models for assessing the effects of climate change on cherry phenology but also as useful tools for breeding strategies.

\section{ACKNOWLEDGEMENTS}

We are grateful to EU COST Cherry FA 1104 for the travel grant to the WG 2 (Cherry phenology and climate change) workshop in Ullensvang in April 2012 to achieve these results. The authors thank Hélène Christmann (INRA) for the pictures.

\section{Literature cited}

Baggiolini, M. (1952). Stades repères du pêcher. Revue Romande d'Agriculture., Viticulture and Arboriculture 4, 29.

Lichou, J., Edin, M. , Tronel, C. and Sounier, R. (1990). Le Cerisier (Paris, France : CTIFL). 
Luedeling, E., Kunz, A., and Blanke, M.M. (2013a). Identification of chilling and heat requirements of cherry trees - a statistical approach. Int. J. Biometeorol. 57 (5), 679-689. PubMed http://dx.doi.org/10.1007.s00484-0120594-y

Luedeling, E., Guo, L., Dai, J., Leslie, C. and Blanke, M.M. (2013b). Differential responses of trees to temperature variation during the chilling and forcing phases. Agric. For. Meteorol. 181, 33-42

http://dx.doi/org/10.1016/i.agrformet.2013.06.018.

Meier, U. et al. (1994). Phänologische Entwicklungsstadien des Kernobstes (Malus domestica Borkh. und Pyrus communis L.), des Steinobstes (Prunus-Arten), der Johannisbeere (Ribes-Arten) und der Erdbeere (Fragaria $x$ ananassa Duch.). Nachrichtenblatt des Deutschen Pflanzenschutzdienstes 46, 141-153. 